\title{
Development of a standards-based city-wide health information exchange for public health in response to COVID-19
}

\section{Authors:}

Bala Hota MD MPH${ }^{1}$, Paul Casey MD MBA루, Anne F. McIntyre PhD MPH², Jawad

Khan', Shafiq Rab MBBS ${ }^{1}$, Aneesh Chopra ${ }^{3}$, Omar Lateef DO ${ }^{1}$, Jennifer E. Layden MD $\mathrm{PhD}^{4}$

${ }^{1}$ Rush University Medical Center, Chicago, IL, $60612{ }^{2}$ Centers for Disease Control and Prevention, Atlanta, GA ${ }^{3}$ Care Journey, ${ }^{4}$ Chicago Department of Public Health, Chicago, IL

\section{Corresponding Author:}

Bala Hota MD, MPH

VP, Chief Analytics Officer

Associate CMO

Professor, Medicine/Infectious Diseases

bala_hota@rush.edu 


\section{Abstract:}

Background: Disease surveillance is a critical function of public health, provides essential information about disease burden, clinical and epidemiologic parameters of disease, and is an important element to effective and timely case and contact tracing. The COVID-19 pandemic has demonstrated the essential role these functions have to preserve public health. Syndromic surveillance, electronic laboratory reporting in the meaningful use program, and the growth of the National Healthcare Safety Network (NHSN) have created linkages between hospitals, commercial labs, and public health that can collect and organize data, often through EHR and order workflows, to improve the timeliness and completeness of reporting. In theory, the standard data formats and exchange methods provided by meaningful use should enable rapid healthcare data exchange in the setting of disruptive healthcare events like a pandemic. In reality, access to data remains challenging, and even if available, often lack conformity to regulated standards.

Objective: We sought to use regulated interoperability standards already in production to generate regional bed capacity awareness, enhance the capture of epidemiological risk factors and clinical variables among COVID-19 tested patients, and reduce the administrative burden of reporting for stakeholders in a manner that could be replicated by other public health agencies. 
medRxiv preprint doi: https://doi.org/10.1101/2020.08.12.20173559; this version posted August 14, 2020. The copyright holder for this preprint (which was not certified by peer review) is the author/funder, who has granted medRxiv a license to display the preprint in perpetuity.

All rights reserved. No reuse allowed without permission.

Methods: Following a public health order mandating data submission, we developed technical infrastructure to combine multiple data feeds from electronic health record systems. We measured the completeness of each feed, and the match rate between feeds.

Results: A cloud-based environment was created that received data from electronic lab reporting, consolidated clinical data architecture, and bed capacity data feeds from sites. Data governance was planned from the project beginning to aid in consensus and principles for data use. 88,906 total persons from CCDA data among 14 facilities, and 408,741 persons from ELR records among 88 facilities, were submitted. Fields routinely absent from ELR feeds included travel histories, clinical symptoms, and comorbidities. CCDA data provided an improvement in the quality of data available for surveillance and was highly complete with $<5 \%$ for all records types with the exception of patient cell phone. $90.1 \%$ of records could be matched between CCDA and ELR feeds.

Conclusions: We describe the development of a city-wide public health data hub for the surveillance of COVID-19 infection. We were able to assess the completeness of existing ELR feeds, augment these feeds with CCDA documents, establish secure transfer methods for data exchange, develop cloud-based architecture to enable secure data storage and analytics, and produced meaningful dashboards for the monitoring of capacity and disease burden. We see this public health and clinical data registry as an 
medRxiv preprint doi: https://doi.org/10.1101/2020.08.12.20173559; this version posted August 14, 2020. The copyright holder for this preprint (which was not certified by peer review) is the author/funder, who has granted medRxiv a license to display the preprint in perpetuity.

All rights reserved. No reuse allowed without permission.

informative example of the power of common standards across electronic records, and a potential template for future extension of the use of standards to improve public health surveillance.

Keywords: SARS-CoV2; COVID-19; Public Health Informatics 


\section{Introduction:}

Since the emergence of SARS CoV-2 from Wuhan, China (1), a global pandemic has been declared(2) and widespread, sustained transmission has been observed across the United States. It has at the time of this writing infected 10.9 million and caused over 520,000 deaths worldwide, and over 2.7 million cases and over 120,000 deaths in the United States, with recent increased incidence rates in states in the Southern and Southwestern U.S.

COVID-19 is a reportable disease in Illinois, and both the Illinois Department of Public Health (IDPH) and Chicago Department of Public Health (CDPH) mandated the reporting of all patents tested for the SARS-CoV-2 virus. Disease surveillance is a critical function of public health, and provides essential information about disease burden, clinical and epidemiologic parameters of disease, and is an important element to effective and timely case and contact tracing. In addition to individual and aggregate level patient data, this pandemic has required careful monitoring of healthcare capacity and utilization to ensure clinical care needs be met.

Support for the public health functions of the surveillance and epidemiology of disease has been embedded in key national informatics initiatives for nearly two decades. These efforts have included syndromic surveillance(3), electronic laboratory reporting(4) in the meaningful use program(5), and the growth of the National 
medRxiv preprint doi: https://doi.org/10.1101/2020.08.12.20173559; this version posted August 14, 2020. The copyright holder for this preprint (which was not certified by peer review) is the author/funder, who has granted medRxiv a license to display the preprint in perpetuity.

All rights reserved. No reuse allowed without permission.

Healthcare Safety Network (NHSN)(6). These programs have created linkages between hospitals, commercial labs, and public health that can collect and organize data, often through EHR and order workflows, to improve the timeliness and completeness of reporting.

In theory, the standard data formats and exchange methods provided by meaningful use should enable rapid healthcare data exchange in the setting of disruptive healthcare events like a pandemic. In reality, access to data remains challenging, and even if available, often lack conformity to regulated standards(7). The current COVID-19 pandemic has revealed gaps in data liquidity and the resultant difficulty in gathering information quickly(8).

In the early phase of the pandemic, $\mathrm{CDPH}$ and health systems aimed to address two major challenges first, the ability to efficiently submit necessary clinical data elements for COVID tested patients, , and second, the ability to capture aggregate capacity data for resource planning in an administratively efficient manner. Despite significant EHR investments among the city's hospitals and health systems, , the inability for electronic health records systems to automate delivery of important data elements to public health surveillance systems meant that providers and health systems had to manually enter data into the public health reporting system. However, the high volume of patients and significant work demands on health systems limited timely, and 
medRxiv preprint doi: https://doi.org/10.1101/2020.08.12.20173559; this version posted August 14, 2020. The copyright holder for this preprint (which was not certified by peer review) is the author/funder, who has granted medRxiv a license to display the preprint in perpetuity.

All rights reserved. No reuse allowed without permission.

complete manual data entry. As the pandemic unfolded, multiple agencies had requested bed and surge capacity information, including NHSN, FEMA, the National guard, the Illinois Department of Public Health, all with slightly varying definitions (Table 1). Locally, an important aspect of capturing the resource capacity data was to monitor surge capacity and assist with coordination of resources. The multiple reporting requirements, varied definitions, and limited mechanisms for automated, real time submission of key resource metrics such as bed capacities raised concern about the ability to locally monitor the resource capacity across our systems.

In response to these challenges the Chicago Department of Public Health issued a public health order requiring electronic data sharing, and partnered with Rush University Medical Center to leverage existing HIT infrastructure for COVID-19 disease to develop a platform for data exchange. Our goals were to use regulated interoperability standards already in production to generate regional bed capacity awareness, enhance the capture of epidemiological risk factors and clinical variables among COVID-19 tested patients, and reduce the administrative burden of reporting for stakeholders in a manner that could be replicated by other public health agencies. As an example of clinically relevant fields of interest for reporting, we compared available fields in data feeds to the CDC PUI form. We also evaluated the completeness of various data sources supplied to the platform and the capacity to link these sources. 


\section{Methods}

\section{Setting}

Chicago is the third largest city in the country and has witnessed a high disease burden of COVID-19, with over 56,000 lab confirmed cases among Chicago residents as of July 15, 2020. This project was conducted by CPDH in partnership with Rush University Medical Center, which was made a third-party agent of CDPH to develop and support the analytics and provide the infrastructure to support the data collection.

\section{Public health notice}

On April 6, 2020, the CDPH issued public health order 2020-4 requiring hospitals in Chicago to share electronic health record data with the public health department(9) for all patients tested for COVID-19. The order outlined a constrained set of data to be submitted for all COVID-19 tested patients. This order was disseminated through CDPH's clinical health alert network, posted on the department's website, and shared with city hospital leadership on calls. CDPH constituted a governance committee comprised of medical directors and informaticists from hospital systems in Chicago.

\section{Data Feeds}

Electronic Lab Records (ELR) feeds were accessed from the Illinois' National Electronic Disease Surveillance System (I-NEDSS) to provide baseline information on lab confirmed cases in the city. To meet public health order 2020-4, Chicago hospitals 
medRxiv preprint doi: https://doi.org/10.1101/2020.08.12.20173559; this version posted August 14, 2020. The copyright holder for this preprint (which was not certified by peer review) is the author/funder, who has granted medRxiv a license to display the preprint in perpetuity.

All rights reserved. No reuse allowed without permission.

were provided multiple mechanisms to submit consolidated clinical data architecture (CCDA) records for COVID-19 tested patients. This included: a) via a secure mailbox that used the DIRECT protocol, a recognized data standard by the Office of the National Coordinator, for the one-way transmission of electronic health records from, as an example, to a centralized instance of Epic for the city, or b) directly to CDPH's Azure instance via DIRECT or an API, which could ingest the CCDA records. In either case the CCDAs were parsed into a database within a dedicated tenant in Azure for analytics. Additionally, a third dataset of NHSN patient safety and hospital capacity was included, which hospitals were asked to either enter into a REDCap database or send electronically to the Azure tenant.

\section{Technical Evaluation}

At the project start, we developed the requirements of a solution to collect data from sites and produce the required analytics. We evaluated the gap between the existing CDC PUI form fields and the electronic data elements available in federal standards based data feeds, and developed a crosswalk of reporting requirements to ensure that the data set could function as a reporting gateway for sites and reduce the burden of reporting. Feeds evaluated were electronic laboratory reporting, consolidated clinical data architecture, and Fast Healthcare Interoperability Resources fields. Comparisons were made based on the latest specifications documents and potential field presence for each. Missingness and usefulness were evaluated among CCDA and 
medRxiv preprint doi: https://doi.org/10.1101/2020.08.12.20173559; this version posted August 14, 2020. The copyright holder for this preprint (which was not certified by peer review) is the author/funder, who has granted medRxiv a license to display the preprint in perpetuity.

All rights reserved. No reuse allowed without permission.

ELR feeds. Missingness refers to the presence of data in the field. Usefulness refers to clean, complete information in data field; $<100 \%$ indicates "unknown" (race, ethnicity, address, etc); for address (PO Boxes, Unknown, Homeless, N/A); phone (no phone, bad number/not enough numbers); ZIP codes < 5 digits or 99999 or 00000 or UUUUU etc.

Records were deduplicated using name and date of birth. Record match rate between CCDA and ELR data feeds was assessed using last and first name and date of birth.

This investigation was part of the ongoing public health response to COVID-19; thus, was determined to be non-research, public health surveillance and exempt from human subjects' research regulations.

\section{Results}

\section{State surveillance system baseline reporting}

In Chicago, a significant proportion of reported cases of SARS CoV-2 infection are reported through ELR. As of June 30, 2020, ELR alone provided 73.7\% of cases, while ELR combined with other modalities accounted for $94 \%$ of reported cases. ELR data reports key fields requested in the CDC PUI form (Table 2) but not all; fields routinely absent from ELR feeds included travel histories, clinical symptoms, and comorbidities. 
medRxiv preprint doi: https://doi.org/10.1101/2020.08.12.20173559; this version posted August 14, 2020. The copyright holder for this preprint (which was not certified by peer review) is the author/funder, who has granted medRxiv a license to display the preprint in perpetuity.

All rights reserved. No reuse allowed without permission.

\section{Response to public health notice}

A public health order was shared via the Health Alert Network in Chicago to all eligible institutions. The order mandated the sharing with CDPH of three main data types: 1) ELR feeds of SARS-CoV-2 tested individuals, which were an existing state mandate; 2) CCDA records from hospitals for SARS-CoV-2 tested patients; and 3) NHSN capacity module reporting, which was asked to be sent centrally to CDPH. These data were requested to be sent at a minimum once per day, by $10 \mathrm{am}$. Sites were also provided contact information for key Rush University Medical Center personnel who were leading the implementation. A series of calls with hospital technical staff were conducted by the Rush CIO (SR) to introduce the project, review rationale, and describe technical approaches.

An Azure hosted and isolated environment was established, with five individual modalities for connectivity; all feeding into a centralized data hub from more than 40 organizations and hundreds of thousands of transactions per week. Over the next 30 days, sites were approached for data sharing; a CDPH data governance committee composed of chief medical officers and chief medical informatics officers from select institutions was created through which issues could be discussed and additional roadmaps could be generated; collaboration with Epic and Cerner EHR developers was established, and mechanisms for enterprise scale sharing was created; and data was sent centrally to the CDPH azure instance. 
medRxiv preprint doi: https://doi.org/10.1101/2020.08.12.20173559; this version posted August 14, 2020. The copyright holder for this preprint (which was not certified by peer review) is the author/funder, who has granted medRxiv a license to display the preprint in perpetuity.

All rights reserved. No reuse allowed without permission.

\section{Technical Architecture}

An overview of the technical architecture of the project is shown in Figure 1, and was designed to maximize security and privacy of data, keeping the CDPH at the center of data use. At a high level, because of the tools from meaningful use adoption, connections existed between stakeholders in the system, and could support secure file sharing with the ability to choose records based on criteria. These tools included: a) standards based representation of clinical data (e.g. CCDA) b) secure methods of data transport both within and external to EHR systems (e.g. CareEverywhere within Epic, Direct mailboxes, and API based authenticated pathways) and c) and existing implementation of complex public health rules within EHRs to identify cases, and submit to public health (e.g. ELR reporting).

A cloud-based environment was created that was totally isolated from the Rush EHR instance and Rush patient records. This environment was built to support over 40 organizations within the city of Chicago and designed to scale across public health departments.

ELR data feeds were the most straightforward to use in the model, as existing connections between hospital systems were present for communicable disease reporting. Hospitals were required to implement new logic at the outset of COVID-19 infections in Chicago to identify and report lab identified cases of COVID-19 to public 
medRxiv preprint doi: https://doi.org/10.1101/2020.08.12.20173559; this version posted August 14, 2020. The copyright holder for this preprint (which was not certified by peer review) is the author/funder, who has granted medRxiv a license to display the preprint in perpetuity.

All rights reserved. No reuse allowed without permission.

health, and tested patients as those are PUIs. ELR feeds are submitted to the state public health agency, which makes these available to the CDPH/local health departments.

To isolate data, Rush created an isolated Azure Data Repository including SQL Warehouse and a CosmosDB for survey forms data was created. We found that not all XDS and direct messages could avoid our EHR instance in our plan, which had to be addressed to enforce separation of data. We addressed this by pulling data from the the Epic staging area. In addition, infrastructure components were created that included an XDS service server, Direct Message communication, a CCD to FHIR service, and integration with Epic via a community health aggregator. Apigee handled the API layer, and services were handled behind Apigee for token control. Data collection via manual entries were handled via REDCap forms with integration via the API into the Azure environment.

\section{Governance}

Data governance was planned from the project beginning to aid in consensus and principles for data use. While the local health department, with its public health orders, was a necessary recipient and user of the data, participants recognized the value of a larger sharing initiative, plus site participation to engage on use cases and mechanisms to leverage the information. The committee was composed of 12 site CMO, CMIO, or technical leads. These leaders also brought content and guidance back to site 
medRxiv preprint doi: https://doi.org/10.1101/2020.08.12.20173559; this version posted August 14, 2020. The copyright holder for this preprint (which was not certified by peer review) is the author/funder, who has granted medRxiv a license to display the preprint in perpetuity.

All rights reserved. No reuse allowed without permission.

participants, and sought to bridge varying degrees of internal technical capabilities

among systems. The committee met weekly and helped to build trust among

participating sites. General principles were modeled after rules implemented for use of

CMS data(10) and were established among sites through this committee. These were:

Openness: Promoting and facilitating the open sharing of knowledge about

COVID-19 data.

Communication: Promoting partnerships across the region to eliminate

duplication of effort, a source of truth for regional data that may enable reduced

administrative burden, and a valuable regional and national resource.

Accountability: Ensuring compliance with approved data management principles and policies. Understanding the objectives of current and future strategic or programmatic initiatives and how they impact, or are impacted by, existing data management principles and policies as well as current privacy and security protocols.

\section{Reporting of bed, supply, and clinical capacity}

Metrics mandated for reporting to multiple agencies and groups for Chicago

hospitals at the time of the hub creation are shown in Table 1. In this inventory, over 100 measures to 4 systems were required: the National Healthcare Safety Network, EMResource, FEMA, and the Illinois National Guard. The systems measure Bed usage, ED Usage, Ventilator usage, Supply usage and need, and Lab testing. Of note, 57 
medRxiv preprint doi: https://doi.org/10.1101/2020.08.12.20173559; this version posted August 14, 2020. The copyright holder for this preprint (which was not certified by peer review) is the author/funder, who has granted medRxiv a license to display the preprint in perpetuity.

All rights reserved. No reuse allowed without permission.

different bed usage measures alone exist between the 4 systems. Though metrics shown had similar definitions, these still require separate administrative efforts for the collection and reporting of the data.

As of July 31, 2020, 14 hospitals in Chicago were reporting data to the hub. For bed capacity reporting, 7 were reporting NHSN data through manual data submission, 2 were reporting through electronic queries from their EHR with electronic submission to the hub, and 14 were submitting to EMResource.

\section{Completeness of reporting via ELR and CCDA}

88,906 total persons from CCDA data among 14 facilities, and 408,741 persons from ELR records among 88 facilities, were submitted. Table 3 shows the volume and completeness of data feeds related to COVID-19 as obtained from CCDA data and with ELR feeds. Individuals with records in these feeds were those with diagnostic testing (i.e molecular) with a Chicago address through July 31, 2020. For those individuals with more than one test reported, data have been deduplicated. Among individuals with CCDA records submitted, $13.1 \%(11,657)$ had positive tests, compared with $13.2 \%$ $(53,968)$ among ELR feeds.

CCDA data provided an improvement in the quality of data available for surveillance. ELR feeds had gaps in the usability, or quality, of race and ethnicity data. With the addition of CCDA information, this content improved. CCDA was also highly 
medRxiv preprint doi: https://doi.org/10.1101/2020.08.12.20173559; this version posted August 14, 2020. The copyright holder for this preprint (which was not certified by peer review) is the author/funder, who has granted medRxiv a license to display the preprint in perpetuity.

All rights reserved. No reuse allowed without permission.

complete with $<5 \%$ for all records types with the exception of patient cell phone, though a contact phone number was highly complete. CCDA, though covering fewer records, also had information related to encounters and hospitalization as well as the presence of comorbidities.

CCDA and ELR data feeds were matched by name and date of birth among $90.1 \%$ of patients. With matching, some improvement in data completeness for the three most incomplete fields was noted: race completeness improved to $20.6 \%(1.4 \%$ improvement), ethnicity improved to $41.5 \%$ (3.5\% improvement), and phone number improved to $31.4 \%(2.8 \%$ improvement $)$

For presentation, data were displayed on a dashboard available for CDPH analysts, via the Azure Power BI platform and are shown in Figure 2.

\section{Discussion}

In this report, we describe the development of a city-wide public health data hub for the surveillance of COVID-19 infection. We were able to assess the completeness of existing ELR feeds, augment these feeds with CCDA documents, establish secure transfer methods for data exchange, develop cloud-based architecture to enable secure data storage and analytics, and produced meaningful dashboards for the monitoring of capacity and disease burden. 
medRxiv preprint doi: https://doi.org/10.1101/2020.08.12.20173559; this version posted August 14, 2020. The copyright holder for this preprint (which was not certified by peer review) is the author/funder, who has granted medRxiv a license to display the preprint in perpetuity.

All rights reserved. No reuse allowed without permission.

Electronic laboratory reporting, or the submission electronically of positive lab tests to public health through implementation of business logic for detection, has been found in multiple studies to improve the timeliness and completeness of reporting(1115), at potentially lower cost(16). A review prior to widespread electronic reporting use found that despite legal mandates for reporting, passive surveillance yielded completeness rates of $23-81 \%$ for communicable diseases with higher rates for active surveillance(17), and for timeliness of reporting, between 10-13 days after lab result dates(18). Electronic laboratory reporting (ELR) systems have resulted in improvements in the reporting of data to public health for surveillance. In states that have implemented ELR, the volume and timeliness have improved 2.3-4.4 fold and 3.8-7.9 days earlier, respectively(19). ELR has been a major advance in that it can improve the completeness of reporting over what is found through passive surveillance(16,20). ELR based systems use a trigger of either a test having been performed or resulting as positive to start a submission workflow.

However, we found that ELR data can be incomplete. In prior reports, ELR data has been found to vary in its completeness: the completeness of fields reported via ELR within basic HL7 v 2.x messages ranges from 38\% (race) to $98 \%$ (date of birth)(20). To improve completeness, groups have proposed 1) increased mandatory fields in ELR HL7 2.x messages(19); 2) augmenting ELR feeds with data from a health information exchange, which improved completeness for race to $60 \%$ (20); and 3) electronic case 
medRxiv preprint doi: https://doi.org/10.1101/2020.08.12.20173559; this version posted August 14, 2020. The copyright holder for this preprint (which was not certified by peer review) is the author/funder, who has granted medRxiv a license to display the preprint in perpetuity.

All rights reserved. No reuse allowed without permission.

report forms which are completed either through automated data capture or manual completion(21). Significant limitations in case reporting have identified during the COVID-19 pandemic, including limited data on key variables such as age, race/ethnicity, hospitalization, and ICU status(22).

Laboratory reporting does not provide all of the information needed for adequate case investigation, however. As our data shows, demographic and risk factor information may not be complete in the HL7 feeds for ELR, and case report forms continue to have a critical role in the work of public health practice. Additionally, comorbid conditions, a significant predictor of disease outcome, are not captured. We found that CCDA data had a broader set of clinical fields, and have the advantage of providing valuable comorbidity information. While only small improvements in completeness were achieved, a high match rate to ELR data makes CCDA a compelling addition to ELR to improve the analytic power of public health data sets.

Initiatives to standardize and automate case report form completion have been developed (23) and piloted (24), which have shown promise at reducing the time to complete reporting. Similar to our results, others have found that health information exchanges show value in prepopulating key elements for reporting through automated matching and searches in the patient record(25). The use of FHIR(26) may provide a viable path for automatic of public health case reporting and reduce administrative 
medRxiv preprint doi: https://doi.org/10.1101/2020.08.12.20173559; this version posted August 14, 2020. The copyright holder for this preprint (which was not certified by peer review) is the author/funder, who has granted medRxiv a license to display the preprint in perpetuity.

All rights reserved. No reuse allowed without permission.

burden: when combined with an ELR based trigger for a case (in this example, sexually transmitted infection cases), an app that executed a FHIR-based query could complete an electronic case report form in $85 \%$ of cases(21). Additionally, all the key components of FHIR based workflows for public health reporting are often in place(27).

A feature of our solution is that it supports the central role of local health departments in data aggregation and reporting. An important component of the public health response in many communities is "home rule" for public health agencies(28), or local jurisdiction and control of policy and approach for local health departments. Present in 48 states, home-rule law empowers local governments to address public health issues and fill gaps in the patchwork of national and state based public health response. In the current pandemic, robust local responses that can enable targeted interventions and planning can allow more sophisticated preparedness planning, pandemic control, and epidemiological analysis.

For the most efficient exchange of data, standards for the structure of data shared, and on the semantic representation of information are critical. In this context, the technical and non-technical handshakes and handoffs related to data are key factors in successful programs. In this setting, technical handshakes are the trust relationships between systems to enable data sharing: the ability to use both authenticated API based transfers, and Direct Mailbox shares accelerated time to implementation for the project. 
Technical handoffs were the ability to have seamless data parsing because of robust standards implemented via meaningful use. The ability to leverage CCDA to increase the completeness of overall PUI reporting, given the greater coverage of fields in the PUI form by CCDA files, is a sign of the value of federal standards for clinical data interchange.

Of more importance were the non-technical "handshakes" - i.e. relationship building and the development of consensus among institutions to enable sharing of data - and "handoffs" - the partnerships between public and private entities. A data governance committee was essential to promote trust, enabled the scaling of the program to new data sets and deeper information within sets. At a time of a surge in COVID-19 cases, a private, academic partner (Rush University Medical Center) with the technical capacity was able to rapidly implement a solution.

We see this public health and clinical data registry as an informative example of the power of common standards across electronic records, and a potential template for future extension of the use of standards to improve public health surveillance. 
medRxiv preprint doi: https://doi.org/10.1101/2020.08.12.20173559; this version posted August 14, 2020. The copyright holder for this preprint (which was not certified by peer review) is the author/funder, who has granted medRxiv a license to display the preprint in perpetuity.

All rights reserved. No reuse allowed without permission.

Acknowledgements: None

Conflicts of Interest: The authors declare no conflicts. 


\section{References}

1. Zhu N, Zhang D, Wang W, Li X, Yang B, Song J, et al. A Novel Coronavirus from

Patients with Pneumonia in China, 2019. New England Journal of Medicine [Internet].

2020 Feb [cited 2020 Apr 27];382(8):727-33. Available from:

https://doi.org/10.1056/NEJMoa2001017

2. WHO Director-General's opening remarks at the media briefing on COVID-19 - 11

March 2020 [Internet]. [cited 2020 Apr 27]. Available from:

https://www.who.int/dg/speeches/detail/who-director-general-s-opening-remarks-atthe-media-briefing-on-covid-19---11-march-2020

3. Syndromic Surveillance (SS) I Meaningful Use I CDC [Internet]. 2020 [cited 2020 Apr 25]. Available from: https://www.cdc.gov/ehrmeaningfuluse/Syndromic.html

4. Electronic Laboratory Reporting (ELR) I Meaningful Use I CDC [Internet]. 2020 [cited 2020 Apr 25]. Available from: https://www.cdc.gov/ehrmeaningfuluse/elr.html

5. Guides I Meaningful Use I CDC [Internet]. 2020 [cited 2020 Apr 25]. Available from: https://www.cdc.gov/ehrmeaningfuluse/guides.html

6. Arnold KE, Thompson ND. Building Data Quality and Confidence in Data Reported to the National Healthcare Safety Network. Infection Control \& Hospital Epidemiology [Internet]. 2012 May [cited 2020 May 3];33(5):446-8. Available from: 
medRxiv preprint doi: https://doi.org/10.1101/2020.08.12.20173559; this version posted August 14, 2020. The copyright holder for this preprint (which was not certified by peer review) is the author/funder, who has granted medRxiv a license to display the preprint in perpetuity.

All rights reserved. No reuse allowed without permission.

https://www.cambridge.org/core/journals/infection-control-and-hospital-

epidemiology/article/building-data-quality-and-confidence-in-data-reported-to-the-

national-healthcare-safety-network/DA0B1FE51A558BB4C5A4AB7CD77BE730

7. Holmgren AJ, Apathy NC, Adler-Milstein J. Barriers to hospital electronic public

health reporting and implications for the COVID-19 pandemic. Journal of the American

Medical Informatics Association [Internet]. [cited 2020 Jul 17]; Available from:

https://academic.oup.com/jamia/article/doi/10.1093/jamia/ocaa112/5842141

8. Strengthening the Public Health Infrastructure: The Role of Data in Controlling the

Spread of COVID-19 [Internet]. 2020. Available from:

http://www.adhocresponsegroup.org/OPCAST_Public_Health_Data_Report_07-28-

20.pdf

9. COVID-19 Orders [Internet]. [cited 2020 May 3]. Available from:

https://www.chicago.gov/content/city/en/sites/covid-19/home/health-orders.html

10. CMS Information Systems Security and Privacy Policy [Internet]. 2019. Available

from: https://www.cms.gov/Research-Statistics-Data-and-Systems/CMS-Information-

Technology/InformationSecurity/Downloads/CMS-IS2P2.pdf

11. Centers for Disease Control and Prevention (CDC). Automated detection and reporting of notifiable diseases using electronic medical records versus passive 
medRxiv preprint doi: https://doi.org/10.1101/2020.08.12.20173559; this version posted August 14, 2020. The copyright holder for this preprint (which was not certified by peer review) is the author/funder, who has granted medRxiv a license to display the preprint in perpetuity.

All rights reserved. No reuse allowed without permission.

surveillance-massachusetts, June 2006-July 2007. MMWR Morbidity and mortality weekly report. 2008 Apr;57(14):373-6.

12. Centers for Disease Control and Prevention (CDC). Potential effects of electronic laboratory reporting on improving timeliness of infectious disease notification-Florida, 2002-2006. MMWR Morbidity and mortality weekly report. 2008 Dec;57(49):1325-8.

13. Centers for Disease Control and Prevention (CDC). Effect of electronic laboratory reporting on the burden of lyme disease surveillance-New Jersey, 2001-2006. MMWR Morbidity and mortality weekly report. 2008 Jan;57(2):42-5.

14. Nguyen TQ, Thorpe L, Makki HA, Mostashari F. Benefits and Barriers to Electronic Laboratory Results Reporting for Notifiable Diseases: The New York City Department of Health and Mental Hygiene Experience. American Journal of Public Health [Internet]. 2007 Apr [cited 2020 Apr 26];97(Suppl 1):S142-5. Available from: https://www.ncbi.nlm.nih.gov/pmc/articles/PMC1854985/

15. Swaan C, van den Broek A, Kretzschmar M, Richardus JH. Timeliness of notification systems for infectious diseases: A systematic literature review. PloS One. 2018;13(6):e0198845.

16. Samoff E, Dibiase L, Fangman MT, Fleischauer AT, Waller AE, MacDonald PDM. We can have it all: Improved surveillance outcomes and decreased personnel costs 
medRxiv preprint doi: https://doi.org/10.1101/2020.08.12.20173559; this version posted August 14, 2020. The copyright holder for this preprint (which was not certified by peer review) is the author/funder, who has granted medRxiv a license to display the preprint in perpetuity.

All rights reserved. No reuse allowed without permission.

associated with electronic reportable disease surveillance, North Carolina, 2010.

American Journal of Public Health. 2013 Dec;103(12):2292-7.

17. Doyle TJ, Glynn MK, Groseclose SL. Completeness of notifiable infectious disease reporting in the United States: An analytical literature review. American Journal of Epidemiology. 2002 May;155(9):866-74.

18. Jajosky RA, Groseclose SL. Evaluation of reporting timeliness of public health surveillance systems for infectious diseases. BMC Public Health [Internet]. 2004 Jul [cited 2020 Apr 26];4:29. Available from:

https://www.ncbi.nlm.nih.gov/pmc/articles/PMC509250/

19. Rajeev D, Staes CJ, Evans RS, Mottice S, Rolfs R, Samore MH, et al. Development of an electronic public health case report using HL7 v2.5 to meet public health needs.

Journal of the American Medical Informatics Association: JAMIA. 17(1):34-41.

20. Dixon BE, McGowan JJ, Grannis SJ. Electronic laboratory data quality and the value of a health information exchange to support public health reporting processes. AMIA Annual Symposium proceedings AMIA Symposium. 2011;2011:322-30.

21. Dixon BE, Taylor DE, Choi M, Riley M, Schneider T, Duke J. Integration of FHIR to Facilitate Electronic Case Reporting: Results from a Pilot Study. Studies in Health Technology and Informatics. 2019 Aug;264:940-4. 
medRxiv preprint doi: https://doi.org/10.1101/2020.08.12.20173559; this version posted August 14, 2020. The copyright holder for this preprint (which was not certified by peer review) is the author/funder, who has granted medRxiv a license to display the preprint in perpetuity.

All rights reserved. No reuse allowed without permission.

22. CDCMMWR. Severe Outcomes Among Patients with Coronavirus Disease 2019

(COVID-19) United States, February 12March 16, 2020. MMWR Morbidity and

Mortality Weekly Report [Internet]. 2020 [cited 2020 Jun 5];69. Available from:

https://www.cdc.gov/mmwr/volumes/69/wr/mm6912e2.htm

23. Mac Kenzie WR, Davidson AJ, Wiesenthal A, Engel JP, Turner K, Conn L, et al. The

Promise of Electronic Case Reporting. Public Health Reports [Internet]. 2016 Nov [cited

2020 Apr 26];131(6):742-6. Available from: https://doi.org/10.1177/0033354916670871

24. Whipple A, Jackson J, Ridderhoff J, Nakashima AK. Piloting Electronic Case

Reporting for Improved Surveillance of Sexually Transmitted Diseases in Utah. Online

Journal of Public Health Informatics [Internet]. 2019 Sep [cited 2020 Apr 25];11(2).

Available from: https://www.ncbi.nlm.nih.gov/pmc/articles/PMC6788887/

25. Painter I, Revere D, Gibson PJ, Baseman J. Leveraging public health's participation

in a Health Information Exchange to improve communicable disease reporting. Online

Journal of Public Health Informatics. 2017;9(2):e186.

26. Index - FHIR v4.0.1 [Internet]. [cited 2020 May 2]. Available from:

https://www.h17.org/fhir/

27. Mishra NK, Duke J, Lenert L, Karki S. Public health reporting and outbreak

response: Synergies with evolving clinical standards for interoperability. Journal of the 
medRxiv preprint doi: https://doi.org/10.1101/2020.08.12.20173559; this version posted August 14, 2020. The copyright holder for this preprint (which was not certified by peer review) is the author/funder, who has granted medRxiv a license to display the preprint in perpetuity.

All rights reserved. No reuse allowed without permission.

American Medical Informatics Association [Internet]. [cited 2020 Jul 17]; Available from:

https://academic.oup.com/jamia/article/doi/10.1093/jamia/ocaa059/5848746

28. McCarty KL, Nelson GD, Hodge JG, Gebbie KM. Major Components and Themes of

Local Public Health Laws in Select U.S. Jurisdictions. Public Health Reports [Internet].

2009 [cited 2020 Jul 16];124(3):458-62. Available from:

https://www.ncbi.nlm.nih.gov/pmc/articles/PMC2663884/ 


\begin{tabular}{|c|c|c|c|}
\hline Type & Name & Definition & Agency/System \\
\hline $\begin{array}{l}\text { Bed } \\
\text { Usage }\end{array}$ & $\begin{array}{l}\text { EMResource - Bed } \\
\text { Availability: Adult Surge } \\
\text { ICU }\end{array}$ & $\begin{array}{l}\text { Number of Adult Surge ICU beds available at } \\
\text { facility. }\end{array}$ & EMResource \\
\hline $\begin{array}{l}\text { Bed } \\
\text { Usage }\end{array}$ & $\begin{array}{l}\text { EMResource - Bed } \\
\text { Availability: Burn }\end{array}$ & $\begin{array}{l}\text { Availability of burn beds. These are thought of as } \\
\text { burn ICU beds, either approved by the American } \\
\text { Burn Association or self-designated. These beds are } \\
\text { NOT to be included in other ICU bed counts. }\end{array}$ & EMResource \\
\hline $\begin{array}{l}\text { Bed } \\
\text { Usage }\end{array}$ & $\begin{array}{l}\text { EMResource - Bed } \\
\text { Availability: Med/Surg }\end{array}$ & $\begin{array}{l}\text { Availability of medical-surgical beds. These are also } \\
\text { thought of as ward beds. These beds may or may } \\
\text { not include cardiac telemetry capability. }\end{array}$ & EMResource \\
\hline $\begin{array}{l}\text { Bed } \\
\text { Usage }\end{array}$ & $\begin{array}{l}\text { EMResource - Bed } \\
\text { Availability: NegFlow }\end{array}$ & $\begin{array}{l}\text { Availability of negative airflow isolation beds. } \\
\text { These provide respiratory isolation. NOTE: This } \\
\text { value may represent available beds included in the } \\
\text { counts of other types. }\end{array}$ & EMResource \\
\hline $\begin{array}{l}\text { Bed } \\
\text { Usage }\end{array}$ & $\begin{array}{l}\text { EMResource - Bed } \\
\text { Availability: OR }\end{array}$ & $\begin{array}{l}\text { Availability of operating rooms which are } \\
\text { equipped, staffed and could be made available for } \\
\text { patient care in a short period of time. }\end{array}$ & EMResource \\
\hline $\begin{array}{l}\text { Bed } \\
\text { Usage }\end{array}$ & $\begin{array}{l}\text { EMResource - Bed } \\
\text { Availability: Other }\end{array}$ & Number of other available beds. & EMResource \\
\hline $\begin{array}{l}\text { Bed } \\
\text { Usage }\end{array}$ & $\begin{array}{l}\text { EMResource - Bed } \\
\text { Availability: Pediatric Surge } \\
\text { ICU }\end{array}$ & Number of pediatric surge beds available at facility. & EMResource \\
\hline $\begin{array}{l}\text { Bed } \\
\text { Usage }\end{array}$ & $\begin{array}{l}\text { EMResource - Bed } \\
\text { Availability: Peds }\end{array}$ & $\begin{array}{l}\text { Availability of pediatrics beds. These are ward } \\
\text { medical/surgical beds for patients } 17 \text {-years-old and } \\
\text { younger. }\end{array}$ & EMResource \\
\hline
\end{tabular}




\begin{tabular}{|c|c|c|c|}
\hline $\begin{array}{l}\text { Bed } \\
\text { Usage }\end{array}$ & $\begin{array}{l}\text { EMResource - Bed } \\
\text { Availability: Psych }\end{array}$ & $\begin{array}{l}\text { Availability of psychiatrics beds. These are ward } \\
\text { beds on a closed/locked psychiatric unit or ward } \\
\text { beds where a patient will be attended by a sitter. }\end{array}$ & EMResource \\
\hline $\begin{array}{l}\text { Bed } \\
\text { Usage }\end{array}$ & $\begin{array}{l}\text { EMResource - Bed } \\
\text { Available: Adult ICU }\end{array}$ & $\begin{array}{l}\text { Availability of adult ICU beds. These can support } \\
\text { critically ill or injured patients, including ventilator } \\
\text { support. }\end{array}$ & EMResource \\
\hline $\begin{array}{l}\text { Bed } \\
\text { Usage }\end{array}$ & $\begin{array}{l}\text { EMResource - Bed } \\
\text { Available: NICU }\end{array}$ & Number of available neonatal ICU beds & EMResource \\
\hline $\begin{array}{l}\text { Bed } \\
\text { Usage }\end{array}$ & $\begin{array}{l}\text { EMResource - Bed } \\
\text { Available: Pediatric ICU }\end{array}$ & $\begin{array}{l}\text { Availability of pediatric ICU beds. Similar to adult } \\
\text { ICU beds, but for patients } 17 \text {-years-old and } \\
\text { younger. }\end{array}$ & EMResource \\
\hline $\begin{array}{l}\text { Bed } \\
\text { Usage }\end{array}$ & $\begin{array}{l}\text { EMResource - Bed Capacity: } \\
\text { Adult ICU }\end{array}$ & $\begin{array}{l}\text { Total number of staffed adult ICU beds. These can } \\
\text { support critically ill or injured patients, including } \\
\text { ventilator support. }\end{array}$ & EMResource \\
\hline $\begin{array}{l}\text { Bed } \\
\text { Usage }\end{array}$ & $\begin{array}{l}\text { EMResource - Bed Capacity: } \\
\text { Burn }\end{array}$ & $\begin{array}{l}\text { Total number of staffed burn beds. These are } \\
\text { thought of as burn ICU beds, either approved by } \\
\text { the American Burn Association or self-designated. } \\
\text { These beds are NOT to be included in other ICU } \\
\text { bed counts. }\end{array}$ & EMResource \\
\hline $\begin{array}{l}\text { Bed } \\
\text { Usage }\end{array}$ & $\begin{array}{l}\text { EMResource - Bed Capacity: } \\
\text { ED }\end{array}$ & Number of licensed ED beds & EMResource \\
\hline $\begin{array}{l}\text { Bed } \\
\text { Usage }\end{array}$ & $\begin{array}{l}\text { EMResource - Bed Capacity: } \\
\text { Medical Surgical }\end{array}$ & $\begin{array}{l}\text { Total number of staffed medical-surgical beds. } \\
\text { These are also thought of as ward beds. These beds } \\
\text { may or may not include cardiac telemetry } \\
\text { capability. }\end{array}$ & EMResource \\
\hline Bed & EMResource - Bed Capacity: & $\begin{array}{l}\text { Total number of staffed negative airflow isolation } \\
\text { beds. These provide respiratory isolation. NOTE: }\end{array}$ & EMResource \\
\hline
\end{tabular}




\begin{tabular}{|c|c|c|c|}
\hline Usage & Neg Flow Isolation & $\begin{array}{l}\text { This value may represent available beds included in } \\
\text { the counts of other types. }\end{array}$ & \\
\hline $\begin{array}{l}\text { Bed } \\
\text { Usage }\end{array}$ & $\begin{array}{l}\text { EMResource - Bed Capacity: } \\
\text { NICU }\end{array}$ & Number of licensed NICU beds & EMResource \\
\hline $\begin{array}{l}\text { Bed } \\
\text { Usage }\end{array}$ & $\begin{array}{l}\text { EMResource - Bed Capacity: } \\
\text { Operating Room }\end{array}$ & $\begin{array}{l}\text { Total number of staffed operating rooms which are } \\
\text { equipped and could be made available for patient } \\
\text { care in a short period of time. }\end{array}$ & EMResource \\
\hline $\begin{array}{l}\text { Bed } \\
\text { Usage }\end{array}$ & $\begin{array}{l}\text { EMResource - Bed Capacity: } \\
\text { Other }\end{array}$ & Number of other licensed beds & EMResource \\
\hline $\begin{array}{l}\text { Bed } \\
\text { Usage }\end{array}$ & $\begin{array}{l}\text { EMResource - Bed Capacity: } \\
\text { Pediatric ICU }\end{array}$ & $\begin{array}{l}\text { Total number of staffed pediatric ICU beds. Similar } \\
\text { to adult ICU beds, but for patients } 17 \text {-years-old and } \\
\text { younger. }\end{array}$ & EMResource \\
\hline $\begin{array}{l}\text { Bed } \\
\text { Usage }\end{array}$ & $\begin{array}{l}\text { EMResource - Bed Capacity: } \\
\text { Pediatrics }\end{array}$ & $\begin{array}{l}\text { Total number of staffed pediatrics beds. These are } \\
\text { ward medical/surgical beds for patients 17-years- } \\
\text { old and younger. }\end{array}$ & EMResource \\
\hline $\begin{array}{l}\text { Bed } \\
\text { Usage }\end{array}$ & $\begin{array}{l}\text { EMResource - Bed Capacity: } \\
\text { Psychiatric }\end{array}$ & $\begin{array}{l}\text { Total number of staffed psychiatrics beds. These are } \\
\text { ward beds on a closed/locked psychiatric unit or } \\
\text { ward beds where a patient will be attended by a } \\
\text { sitter. }\end{array}$ & EMResource \\
\hline $\begin{array}{l}\text { Bed } \\
\text { Usage }\end{array}$ & $\begin{array}{l}\text { EMResource - Ventilators } \\
\text { Available Surge }\end{array}$ & Number of available surge ventilators at facility. & EMResource \\
\hline $\begin{array}{l}\text { Bed } \\
\text { Usage }\end{array}$ & FEMA - All hospital beds & $\begin{array}{l}\text { Total number of all staffed inpatient and outpatient } \\
\text { beds in your hospital, including all overflow and } \\
\text { surge/expansion beds used for inpatients and for } \\
\text { outpatients (includes all ICU beds). }\end{array}$ & FEMA Daily Report \\
\hline Bed & FEMA - Hospital Inpatient & Total number of staffed inpatient beds that are & FEMA Daily Report \\
\hline
\end{tabular}




\begin{tabular}{|c|c|c|c|}
\hline Usage & bed occupancy & occupied & \\
\hline $\begin{array}{l}\text { Bed } \\
\text { Usage }\end{array}$ & $\begin{array}{l}\text { FEMA - Hospital Inpatient } \\
\text { Beds }\end{array}$ & $\begin{array}{l}\text { Total number of staffed inpatient beds in your } \\
\text { hospital including all overflow and } \\
\text { surge/expansion beds used for inpatients (includes } \\
\text { all ICU beds) }\end{array}$ & FEMA Daily Report \\
\hline $\begin{array}{l}\text { Bed } \\
\text { Usage }\end{array}$ & FEMA - Hospital Onset & $\begin{array}{l}\text { Patients currently hospitalized in an inpatient bed } \\
\text { with onset of suspected or confirmed COVID-19 } \\
\text { fourteen or more days after hospital admission due } \\
\text { to a condition other than COVID-19 }\end{array}$ & FEMA Daily Report \\
\hline $\begin{array}{l}\text { Bed } \\
\text { Usage }\end{array}$ & $\begin{array}{l}\text { FEMA - Hospitalized and } \\
\text { ventilated COVID patient }\end{array}$ & $\begin{array}{l}\text { Patients currently hospitalized in an inpatient bed } \\
\text { who have suspected or confirmed COVID-19 and } \\
\text { are on a mechanical ventilator }\end{array}$ & FEMA Daily Report \\
\hline $\begin{array}{l}\text { Bed } \\
\text { Usage }\end{array}$ & $\begin{array}{l}\text { FEMA - Hospitalized } \\
\text { COVID patients }\end{array}$ & $\begin{array}{l}\text { Patients currently hospitalized in an inpatient bed } \\
\text { who have suspected or confirmed COVID-19 }\end{array}$ & FEMA Daily Report \\
\hline $\begin{array}{l}\text { Bed } \\
\text { Usage }\end{array}$ & FEMA - ICU bed occupancy & $\begin{array}{l}\text { Total number of staffed inpatient ICU beds that are } \\
\text { occupied }\end{array}$ & FEMA Daily Report \\
\hline $\begin{array}{l}\text { Bed } \\
\text { Usage }\end{array}$ & FEMA - ICU Beds & Total number of staffed inpatient ICU beds & FEMA Daily Report \\
\hline $\begin{array}{l}\text { Bed } \\
\text { Usage }\end{array}$ & $\begin{array}{l}\text { FEMA - Total Beds } \\
\text { (Temporary) }\end{array}$ & $\begin{array}{l}\text { The current number of physical usable beds in the } \\
\text { facility. If the bed is not currently staffed, but usable } \\
\text { and has the potential to be staffed, it should be } \\
\text { counted. The same would apply to a blocked bed. If } \\
\text { the bed is currently blocked, but is usable bed, it } \\
\text { should be counted. }\end{array}$ & FEMA Daily Report \\
\hline $\begin{array}{l}\text { Bed } \\
\text { Usage }\end{array}$ & $\begin{array}{l}\text { FEMA - Total Occupied } \\
\text { Beds (Temporary) }\end{array}$ & $\begin{array}{l}\text { The number of beds currently occupied with } \\
\text { patients. This also includes any patient that may be } \\
\text { located in an outpatient area within the facility (e.g. }\end{array}$ & FEMA Daily Report \\
\hline
\end{tabular}


ED or PACU bays) that have an inpatient or observation order).

\begin{tabular}{|c|c|c|c|}
\hline $\begin{array}{l}\text { Bed } \\
\text { Usage }\end{array}$ & $\begin{array}{l}\text { ING - Airborne Isolation } \\
\text { Beds }\end{array}$ & $\begin{array}{l}\text { Total number of AIIR (airborne infection isolation } \\
\text { room) beds at hospital? }\end{array}$ & $\begin{array}{l}\text { Illinois National Guard } \\
\text { Survey }\end{array}$ \\
\hline $\begin{array}{l}\text { Bed } \\
\text { Usage }\end{array}$ & $\begin{array}{l}\text { ING - Airborne Isolation } \\
\text { Beds Available }\end{array}$ & $\begin{array}{l}\text { Total number of AIIR (airborne infection isolation } \\
\text { room) beds at hospital available? }\end{array}$ & $\begin{array}{l}\text { Illinois National Guard } \\
\text { Survey }\end{array}$ \\
\hline $\begin{array}{l}\text { Bed } \\
\text { Usage }\end{array}$ & $\begin{array}{l}\text { ING - Alternative Care Site - } \\
\text { Isolation }\end{array}$ & Does this facility have isolation capabilties? & $\begin{array}{l}\text { Illinois National Guard } \\
\text { Survey }\end{array}$ \\
\hline $\begin{array}{l}\text { Bed } \\
\text { Usage }\end{array}$ & $\begin{array}{l}\text { ING - Alternative Care Site - } \\
\text { Respiratory } \\
\text { Illness/Ventilation }\end{array}$ & $\begin{array}{l}\text { Can this facility handle patients with respiratory } \\
\text { illness (ventilation)? }\end{array}$ & $\begin{array}{l}\text { Illinois National Guard } \\
\text { Survey }\end{array}$ \\
\hline $\begin{array}{l}\text { Bed } \\
\text { Usage }\end{array}$ & ING - ICU Beds & $\begin{array}{l}\text { Total number of ICU (Intensive Care Unit) beds at } \\
\text { hospital? }\end{array}$ & $\begin{array}{l}\text { Illinois National Guard } \\
\text { Survey }\end{array}$ \\
\hline $\begin{array}{l}\text { Bed } \\
\text { Usage }\end{array}$ & ING - ICU Beds Available & $\begin{array}{l}\text { Total number of ICU (Intensive Care Unit) beds at } \\
\text { hospital available? }\end{array}$ & $\begin{array}{l}\text { Illinois National Guard } \\
\text { Survey }\end{array}$ \\
\hline $\begin{array}{l}\text { Bed } \\
\text { Usage }\end{array}$ & ING - Medical/Surgical Beds & Total number of medical/surgical beds at hospital? & $\begin{array}{l}\text { Illinois National Guard } \\
\text { Survey }\end{array}$ \\
\hline $\begin{array}{l}\text { Bed } \\
\text { Usage }\end{array}$ & $\begin{array}{l}\text { ING - Medical/Surgical Beds } \\
\text { Available }\end{array}$ & $\begin{array}{l}\text { Total number of medical/surgical beds at hospital } \\
\text { available? }\end{array}$ & $\begin{array}{l}\text { Illinois National Guard } \\
\text { Survey }\end{array}$ \\
\hline $\begin{array}{l}\text { Bed } \\
\text { Usage }\end{array}$ & ING - Other Staffed Beds & Total number of other staffed beds at hospital? & $\begin{array}{l}\text { Illinois National Guard } \\
\text { Survey }\end{array}$ \\
\hline $\begin{array}{l}\text { Bed } \\
\text { Usage }\end{array}$ & $\begin{array}{l}\text { ING - Other Staffed Beds } \\
\text { Available }\end{array}$ & $\begin{array}{l}\text { Total number of other staffed beds at hospital } \\
\text { available? }\end{array}$ & $\begin{array}{l}\text { Illinois National Guard } \\
\text { Survey }\end{array}$ \\
\hline $\begin{array}{l}\text { Bed } \\
\text { Usage }\end{array}$ & ING - Unlicensed Beds & $\begin{array}{l}\text { Does the hospital have unlicensed beds that could } \\
\text { be opened if allowed by IDPH hospital licensing? }\end{array}$ & $\begin{array}{l}\text { Illinois National Guard } \\
\text { Survey }\end{array}$ \\
\hline Bed & ING - Unlicensed Beds - & How many beds could be opened? & Illinois National Guard \\
\hline
\end{tabular}




\begin{tabular}{|c|c|c|c|}
\hline Usage & Count & & Survey \\
\hline $\begin{array}{l}\text { Bed } \\
\text { Usage }\end{array}$ & NHSN - All Hospital Beds & $\begin{array}{l}\text { Enter the total number of all hospital beds, } \\
\text { including inpatient and outpatient beds. All staffed, } \\
\text { licensed, and overflow and surge/expansion beds } \\
\text { used for inpatients or outpatients. This includes } \\
\text { ICU beds. }\end{array}$ & NHSN Daily Report \\
\hline $\begin{array}{l}\text { Bed } \\
\text { Usage }\end{array}$ & NHSN - Deaths & $\begin{array}{l}\text { Enter the number of patients with suspected or } \\
\text { confirmed COVID-19 who died in the hospital, ED, } \\
\text { or any overflow location. This includes patients } \\
\text { with laboratory-confirmed or clinically diagnosed } \\
\text { COVID-19. Please enter the count of deaths newly } \\
\text { occurred, at the time the data is collected instead of } \\
\text { the cumulated number of deaths. }\end{array}$ & NHSN Daily Report \\
\hline $\begin{array}{l}\text { Bed } \\
\text { Usage }\end{array}$ & NHSN - ED/Overflow & $\begin{array}{l}\text { Enter the number of patients with suspected or } \\
\text { confirmed COVID-19 who are in the Emergency } \\
\text { Department(ED) or any overflow/expansion } \\
\text { location awaiting placement in an inpatient bed at } \\
\text { the time the data is collected. This includes patients } \\
\text { with laboratory-confirmed or clinically diagnosed } \\
\text { COVID-19. Overflow locations include any physical } \\
\text { locations created to accommodate patients include } \\
\text { but not limited to } 24 \text {-hour observation units, } \\
\text { hallways, parking lots, or tents. }\end{array}$ & NHSN Daily Report \\
\hline $\begin{array}{l}\text { Bed } \\
\text { Usage }\end{array}$ & $\begin{array}{l}\text { NHSN - ED/Overflow and } \\
\text { Ventilated }\end{array}$ & $\begin{array}{l}\text { Enter the number of patients with suspected or } \\
\text { confirmed COVID-19 who are in the ED or any } \\
\text { overflow/expansion location on a mechanical } \\
\text { ventilator* at the time the data is collected. This } \\
\text { includes patients with laboratory-confirmed or }\end{array}$ & NHSN Daily Report \\
\hline
\end{tabular}


clinically diagnosed COVID-19. *Ventilator: Any

device used to support, assist or control respiration (inclusive of the weaning period) through the application of positive pressure to the airway when delivered via an artificial airway, specifically an oral/nasal endotracheal or tracheostomy tube. Note: Ventilation and lung expansion devices that deliver positive pressure to the airway (for example: CPAP, BiPAP, bi-level, IPPB and PEEP) via non-invasive means (for example: nasal prongs, nasal mask, full face mask, total mask, etc.) are not considered ventilators unless positive pressure is delivered via an artificial airway (oral/nasal endotracheal or tracheostomy tube).

\begin{tabular}{|c|c|c|c|}
\hline $\begin{array}{l}\text { Bed } \\
\text { Usage }\end{array}$ & $\begin{array}{l}\text { NHSN - Hospital Inpatient } \\
\text { Beds }\end{array}$ & $\begin{array}{l}\text { Required. Enter the total number of all inpatient } \\
\text { beds, including all staffed, licensed, and overflow } \\
\text { and surge/expansion beds created for inpatient } \\
\text { care. This includes intensive care unit (ICU) beds. }\end{array}$ & NHSN Daily Report \\
\hline $\begin{array}{l}\text { Bed } \\
\text { Usage }\end{array}$ & $\begin{array}{l}\text { NHSN - Hospital Inpatient } \\
\text { Beds Occupancy }\end{array}$ & $\begin{array}{l}\text { Enter the total number of staffed inpatient beds } \\
\text { occupied by patients at the time the data is } \\
\text { collected, including all staffed, licensed, and } \\
\text { overflow and surge/expansion beds created for } \\
\text { inpatient care. This includes ICU beds. }\end{array}$ & NHSN Daily Report \\
\hline $\begin{array}{l}\text { Bed } \\
\text { Usage }\end{array}$ & NHSN - Hospital Onset & $\begin{array}{l}\text { Enter the number of patients hospitalized in an } \\
\text { inpatient bed at the time the data is collected with } \\
\text { onset of suspected or confirmed COVID-19 fourteen } \\
\text { or more days after hospitalization (admission date = } \\
\text { hospital day 1). This includes laboratory-confirmed }\end{array}$ & NHSN Daily Report \\
\hline
\end{tabular}




\begin{tabular}{|c|c|c|c|}
\hline & & or clinically diagnosed COVID-19 cases. & \\
\hline $\begin{array}{l}\text { Bed } \\
\text { Usage }\end{array}$ & NHSN - Hospitalized & $\begin{array}{l}\text { Enter the number of patients hospitalized in an } \\
\text { inpatient bed at the time the data is collected who } \\
\text { have suspected or confirmed COVID-19. This } \\
\text { includes the patients with laboratory-confirmed or } \\
\text { clinically diagnosed COVID-19. Confirmed: A } \\
\text { patient with a laboratoryconfirmed COVID-19 } \\
\text { diagnosis Suspected: A patient without a laboratory } \\
\text { confirmed COVID-19 diagnosis who, in accordance } \\
\text { with CDC's Interim Public Health Guidance for } \\
\text { Evaluating Persons Under Investigation (PUIs), has } \\
\text { signs and symptoms compatible with COVID-19 } \\
\text { (most patients with confirmed COVID-19 have } \\
\text { developed fever and/or symptoms of acute } \\
\text { respiratory illness, such as cough, shortness of } \\
\text { breath or myalgia/fatigue). }\end{array}$ & NHSN Daily Report \\
\hline $\begin{array}{l}\text { Bed } \\
\text { Usage }\end{array}$ & $\begin{array}{l}\text { NHSN - Hospitalized and } \\
\text { Ventilated }\end{array}$ & $\begin{array}{l}\text { Enter the number of patients hospitalized in an } \\
\text { inpatient bed who have suspected or confirmed } \\
\text { COVID-19 and are currently on a mechanical } \\
\text { ventilator* at the time the data is collected. This } \\
\text { includes the patients with laboratory-confirmed or } \\
\text { clinically diagnosed COVID-19. *Ventilator: Any } \\
\text { device used to support, assist or control respiration } \\
\text { (inclusive of the weaning period) through the } \\
\text { application of positive pressure to the airway when } \\
\text { delivered via an artificial airway, specifically an } \\
\text { oral/nasal endotracheal or tracheostomy tube. Note: } \\
\text { Ventilation and lung expansion devices that deliver }\end{array}$ & NHSN Daily Report \\
\hline
\end{tabular}




\begin{tabular}{|c|c|c|c|}
\hline & & $\begin{array}{l}\text { positive pressure to the airway (for example: CPAP, } \\
\text { BiPAP, bi-level, IPPB and PEEP) via non-invasive } \\
\text { means (for example: nasal prongs, nasal mask, full } \\
\text { face mask, total mask, etc.) are not considered } \\
\text { ventilators unless positive pressure is delivered via } \\
\text { an artificial airway (oral/nasal endotracheal or } \\
\text { tracheostomy tube). }\end{array}$ & \\
\hline $\begin{array}{l}\text { Bed } \\
\text { Usage }\end{array}$ & $\begin{array}{l}\text { NHSN - ICU Bed } \\
\text { Occupancy }\end{array}$ & $\begin{array}{l}\text { Enter the total number of staffed ICU beds occupied } \\
\text { by patients at the time the data is collected. }\end{array}$ & NHSN Daily Report \\
\hline $\begin{array}{l}\text { Bed } \\
\text { Usage }\end{array}$ & NHSN - ICU Beds & $\begin{array}{l}\text { Enter the total number of staffed Intensive Care } \\
\text { Unit (ICU) beds. }\end{array}$ & NHSN Daily Report \\
\hline ED Usage & $\begin{array}{l}\text { EMResource - Bed } \\
\text { Availability: ED }\end{array}$ & Please add your ED bed availability. & EMResource \\
\hline Ed Usage & $\begin{array}{l}\text { EMResource - Decon } \\
\text { Throughput }\end{array}$ & $\begin{array}{l}\text { The number of patients facility can decontaminate } \\
\text { every hour. }\end{array}$ & EMResource \\
\hline ED Usage & FEMA - ED/Overflow & $\begin{array}{l}\text { Patients with suspected or confirmed COVID-19 } \\
\text { who currently are in the Emergency Department } \\
\text { (ED) or any overflow location awaiting an inpatient } \\
\text { bed }\end{array}$ & FEMA Daily Report \\
\hline ED Usage & $\begin{array}{l}\text { FEMA - ED/Overflow and } \\
\text { Vented }\end{array}$ & $\begin{array}{l}\text { Patients with suspected or confirmed COVID-19 } \\
\text { who currently are in the ED or any overflow } \\
\text { location awaiting an inpatient bed and on a } \\
\text { mechanical ventilator }\end{array}$ & FEMA Daily Report \\
\hline ED Usage & $\begin{array}{l}\text { ING - Alternative Care Site - } \\
\text { Availability }\end{array}$ & $\begin{array}{l}\text { Has the hospital designated (or have access to a site } \\
\text { to serve as) an Alternate Care Site (remote location } \\
\text { the hospital can stand up to handle surge of } \\
\text { patients)? }\end{array}$ & $\begin{array}{l}\text { Illinois National Guard } \\
\text { Survey }\end{array}$ \\
\hline
\end{tabular}




\begin{tabular}{|c|c|c|c|}
\hline ED Usage & $\begin{array}{l}\text { ING - Alternative Care Site - } \\
\text { Operation }\end{array}$ & Is this facility operational? & $\begin{array}{l}\text { Illinois National Guard } \\
\text { Survey }\end{array}$ \\
\hline ED Usage & $\begin{array}{l}\text { ING - External } \\
\text { Triage/Screening - } \\
\text { Availability }\end{array}$ & $\begin{array}{l}\text { Does the hospital have an external traige/screening } \\
\text { area away from the emergency department or } \\
\text { outside of the hospital? }\end{array}$ & $\begin{array}{l}\text { Illinois National Guard } \\
\text { Survey }\end{array}$ \\
\hline ED Usage & $\begin{array}{l}\text { ING - External } \\
\text { Triage/Screening - } \\
\text { Operation }\end{array}$ & Is the external triage/screening area in operation? & $\begin{array}{l}\text { Illinois National Guard } \\
\text { Survey }\end{array}$ \\
\hline ED Usage & $\begin{array}{l}\text { ING - Hospital Entrance for } \\
\text { COVID Patients }\end{array}$ & $\begin{array}{l}\text { Has the hospital identified an area for potential } \\
\text { COVID-19 patients to enter the hospital other then } \\
\text { the emergency department? }\end{array}$ & $\begin{array}{l}\text { Illinois National Guard } \\
\text { Survey }\end{array}$ \\
\hline $\begin{array}{l}\text { Lab } \\
\text { Testing }\end{array}$ & $\begin{array}{l}\text { FEMA - COVID-19 Patients } \\
\text { Confirmed (Temporary) }\end{array}$ & $\begin{array}{l}\text { The number of patients anywhere in the facility that } \\
\text { are currently positive with COVID- } 19 \text {. This does not } \\
\text { include patients that were once positive but are } \\
\text { now negative. }\end{array}$ & FEMA Daily Report \\
\hline $\begin{array}{l}\text { Lab } \\
\text { Testing }\end{array}$ & $\begin{array}{l}\text { FEMA - COVID-19 Patients } \\
\text { Under Investigation } \\
\text { (Temporary) }\end{array}$ & $\begin{array}{l}\text { The number of patients anywhere in the facility that } \\
\text { are currently under investigation suspected to have } \\
\text { COVID-19 }\end{array}$ & FEMA Daily Report \\
\hline $\begin{array}{l}\text { Lab } \\
\text { Testing }\end{array}$ & $\begin{array}{l}\text { FEMA - Cumulative } \\
\text { Diagnostic Tests } \\
\text { Ordered/Recieved }\end{array}$ & All tests ordered to date; Rush internal tests only & FEMA Daily Report \\
\hline $\begin{array}{l}\text { Lab } \\
\text { Testing }\end{array}$ & $\begin{array}{l}\text { FEMA - Cumulative } \\
\text { Negative COVID-19 Tests }\end{array}$ & $\begin{array}{l}\text { All negative test results released to date; Rush } \\
\text { internal tests only }\end{array}$ & FEMA Daily Report \\
\hline $\begin{array}{l}\text { Lab } \\
\text { Testing }\end{array}$ & $\begin{array}{l}\text { FEMA - Cumulative } \\
\text { Positive COVID-19 Tests }\end{array}$ & $\begin{array}{l}\text { All positive test results released to date; Rush } \\
\text { internal tests only }\end{array}$ & FEMA Daily Report \\
\hline Lab & FEMA - Cumulative Tests & All tests with results released to date; Rush internal & FEMA Daily Report \\
\hline
\end{tabular}




\begin{tabular}{|c|c|c|c|}
\hline Testing & Performed & tests only & \\
\hline $\begin{array}{l}\text { Lab } \\
\text { Testing }\end{array}$ & $\begin{array}{l}\text { FEMA - New Diagnostic } \\
\text { Tests Ordered/Received }\end{array}$ & $\begin{array}{l}\text { Midnight to midnight cutoff, tests ordered on } \\
\text { previous date queried; Rush internal tests only }\end{array}$ & FEMA Daily Report \\
\hline $\begin{array}{l}\text { Lab } \\
\text { Testing }\end{array}$ & $\begin{array}{l}\text { FEMA - New Negative } \\
\text { COVID-19 Tests }\end{array}$ & $\begin{array}{l}\text { Midnight to midnight cutoff, negative test results } \\
\text { released on previous date queried; Rush internal } \\
\text { tests only }\end{array}$ & FEMA Daily Report \\
\hline $\begin{array}{l}\text { Lab } \\
\text { Testing }\end{array}$ & $\begin{array}{l}\text { FEMA - New Positive } \\
\text { COVID-19 Tests }\end{array}$ & $\begin{array}{l}\text { Midnight to midnight cutoff, positive test results } \\
\text { released on previous date queried; Rush internal } \\
\text { tests only }\end{array}$ & FEMA Daily Report \\
\hline $\begin{array}{l}\text { Lab } \\
\text { Testing }\end{array}$ & FEMA - New Tests Resulted & $\begin{array}{l}\text { Midnight to midnight cutoff, test results released on } \\
\text { previous date queried; Rush internal tests only }\end{array}$ & FEMA Daily Report \\
\hline Other & FEMA - Deaths & $\begin{array}{l}\text { Number of patients with suspected or confirmed } \\
\text { COVID-19 who died in the hospital, ED, or any } \\
\text { overflow location on the date for which you are } \\
\text { reporting }\end{array}$ & FEMA Daily Report \\
\hline Other & ING - Security & Is there a security need? & $\begin{array}{l}\text { Illinois National Guard } \\
\text { Survey }\end{array}$ \\
\hline Supplies & $\begin{array}{l}\text { FEMA - On-hand supply of } \\
\text { N95 masks }\end{array}$ & $\begin{array}{l}\text { _Zero days _ } 1-3 \text { days _ } 4-14 \text { days _ } 15 \text { or more } \\
\text { days }\end{array}$ & FEMA Daily Report \\
\hline Supplies & $\begin{array}{l}\text { ING - Alternative Care Site - } \\
\text { Additional Resources }\end{array}$ & Is additional resources need to operate the facility? & $\begin{array}{l}\text { Illinois National Guard } \\
\text { Survey }\end{array}$ \\
\hline Supplies & $\begin{array}{l}\text { ING - Alternative Care Site - } \\
\text { Establishment }\end{array}$ & $\begin{array}{l}\text { Is there a need for the state to assist with the } \\
\text { establishment? }\end{array}$ & $\begin{array}{l}\text { Illinois National Guard } \\
\text { Survey }\end{array}$ \\
\hline Supplies & $\begin{array}{l}\text { ING - Alternative Care Site - } \\
\text { Support }\end{array}$ & $\begin{array}{l}\text { What support does the hospital need to operate the } \\
\text { facility? }\end{array}$ & $\begin{array}{l}\text { Illinois National Guard } \\
\text { Survey }\end{array}$ \\
\hline Supplies & ING - Blood Shortage & Does the hospital have blood shortages? & Illinois National Guard \\
\hline
\end{tabular}




\begin{tabular}{|c|c|c|c|}
\hline & & & Survey \\
\hline Supplies & $\begin{array}{l}\text { ING - Critical Resource } \\
\text { Needs - Current }\end{array}$ & $\begin{array}{l}\text { What are your critical resource and support needs - } \\
\text { currently? }\end{array}$ & $\begin{array}{l}\text { Illinois National Guard } \\
\text { Survey }\end{array}$ \\
\hline Supplies & $\begin{array}{l}\text { ING - Critical Resource } \\
\text { Needs - Next } 12 \text { hours }\end{array}$ & $\begin{array}{l}\text { What are your critical resource and support needs - } \\
\text { Next } 12 \text { hours? }\end{array}$ & $\begin{array}{l}\text { Illinois National Guard } \\
\text { Survey }\end{array}$ \\
\hline Supplies & $\begin{array}{l}\text { ING - PPE - Face Shields } \\
\text { Inventory }\end{array}$ & How many face shields do you have on-hand? & $\begin{array}{l}\text { Illinois National Guard } \\
\text { Survey }\end{array}$ \\
\hline Supplies & $\begin{array}{l}\text { ING - PPE - Face Shields } \\
\text { Request }\end{array}$ & How many face shields do you need to request? & $\begin{array}{l}\text { Illinois National Guard } \\
\text { Survey }\end{array}$ \\
\hline Supplies & $\begin{array}{l}\text { ING - PPE - Gloves } \\
\text { Inventory }\end{array}$ & How many gloves do you have on-hand? & $\begin{array}{l}\text { Illinois National Guard } \\
\text { Survey }\end{array}$ \\
\hline Supplies & ING - PPE - Gloves Request & How many gloves do you need to request? & $\begin{array}{l}\text { Illinois National Guard } \\
\text { Survey }\end{array}$ \\
\hline Supplies & $\begin{array}{l}\text { ING - PPE - Gowns } \\
\text { Inventory }\end{array}$ & How many gowns do you have on-hand? & $\begin{array}{l}\text { Illinois National Guard } \\
\text { Survey }\end{array}$ \\
\hline Supplies & ING - PPE - Gowns Request & How many gowns do you need to request? & $\begin{array}{l}\text { Illinois National Guard } \\
\text { Survey }\end{array}$ \\
\hline Supplies & $\begin{array}{l}\text { ING - PPE - Masks } \\
\text { Inventory }\end{array}$ & How many masks do you have on-hand? & $\begin{array}{l}\text { Illinois National Guard } \\
\text { Survey }\end{array}$ \\
\hline Supplies & ING - PPE - Masks Request & How many masks do you need to request? & $\begin{array}{l}\text { Illinois National Guard } \\
\text { Survey }\end{array}$ \\
\hline Supplies & $\begin{array}{l}\text { ING - PPE - Themometers } \\
\text { Request }\end{array}$ & How many thermometers do you need to request? & $\begin{array}{l}\text { Illinois National Guard } \\
\text { Survey }\end{array}$ \\
\hline Supplies & $\begin{array}{l}\text { ING - PPE - Thermometers } \\
\text { Inventory }\end{array}$ & How many thermometers do you have on-hand? & $\begin{array}{l}\text { Illinois National Guard } \\
\text { Survey }\end{array}$ \\
\hline
\end{tabular}




\begin{tabular}{|c|c|c|c|}
\hline Supplies & ING - PPE Request & $\begin{array}{l}\text { Did you submit a resource request to the county for } \\
\text { Personal Protective Equipment for your facility? }\end{array}$ & $\begin{array}{l}\text { Illinois National Guard } \\
\text { Survey }\end{array}$ \\
\hline Supplies & ING - Supplies for EMS & $\begin{array}{l}\text { Is the hospital able to replace supplies for EMS } \\
\text { providers sent to the emergency department and } \\
\text { for inpatients? }\end{array}$ & $\begin{array}{l}\text { Illinois National Guard } \\
\text { Survey }\end{array}$ \\
\hline Supplies & ING - Surge Situation & Is the hospital in a surge situation? & $\begin{array}{l}\text { Illinois National Guard } \\
\text { Survey }\end{array}$ \\
\hline Supplies & $\begin{array}{l}\text { ING - Urgent Resource } \\
\text { Requests }\end{array}$ & $\begin{array}{l}\text { Does the hospital have any urgent (i.e. needed with } \\
6 \text { hours) resource requests? }\end{array}$ & $\begin{array}{l}\text { Illinois National Guard } \\
\text { Survey }\end{array}$ \\
\hline $\begin{array}{l}\text { Ventilator } \\
\text { Use }\end{array}$ & $\begin{array}{l}\text { EMResource - Available: } \\
\text { Vents }\end{array}$ & $\begin{array}{l}\text { Total number of full feature ventilators available to } \\
\text { the facility that can support patients }>5 \mathrm{~kg} \text { and } \\
\text { above }\end{array}$ & EMResource \\
\hline $\begin{array}{l}\text { Ventilator } \\
\text { Use }\end{array}$ & $\begin{array}{l}\text { EMResource - Capacity: } \\
\text { Vents }\end{array}$ & $\begin{array}{l}\text { The total number of ventilators at this facility (in- } \\
\text { use and available). }\end{array}$ & EMResource \\
\hline $\begin{array}{l}\text { Ventilator } \\
\text { Use }\end{array}$ & $\begin{array}{l}\text { FEMA - COVID-19 Patients } \\
\text { Using Ventilation } \\
\text { (Temporary) }\end{array}$ & $\begin{array}{l}\text { The current number of confirmed COVID-19 } \\
\text { patients (laboratory confirmed or clinically } \\
\text { diagnosed) using ventilators. }\end{array}$ & FEMA Daily Report \\
\hline $\begin{array}{l}\text { Ventilator } \\
\text { Use }\end{array}$ & $\begin{array}{l}\text { FEMA - Mechanical } \\
\text { Ventilators }\end{array}$ & Total number of ventilators available & FEMA Daily Report \\
\hline $\begin{array}{l}\text { Ventilator } \\
\text { Use }\end{array}$ & $\begin{array}{l}\text { FEMA - Mechanical } \\
\text { Ventilators in use }\end{array}$ & Total number of ventilators in use & FEMA Daily Report \\
\hline $\begin{array}{l}\text { Ventilator } \\
\text { Use }\end{array}$ & ING - Ventilators & Total number of ventilators in use at hospital? & $\begin{array}{l}\text { Illinois National Guard } \\
\text { Survey }\end{array}$ \\
\hline $\begin{array}{l}\text { Ventilator } \\
\text { Use }\end{array}$ & ING - Ventilators Available & $\begin{array}{l}\text { Total number of ventilators in use at hospital } \\
\text { available? }\end{array}$ & $\begin{array}{l}\text { Illinois National Guard } \\
\text { Survey }\end{array}$ \\
\hline Ventilator & NHSN - Mechanical & Enter the total number of mechanical ventilators in & NHSN Daily Report \\
\hline
\end{tabular}




$\begin{array}{lll}\text { Use } & \text { Ventialtors in Use } & \begin{array}{l}\text { use at the time the data is collected, including } \\ \text { anesthesia machines and portable/transport } \\ \text { ventilators. Include BiPAP machines if the hospital } \\ \text { uses BiPAP to deliver positive pressure ventilation } \\ \text { via artificial airways. }\end{array} \\ \begin{array}{ll}\text { Ventilator } \\ \text { Use }\end{array} \quad \text { Ventilators } & \begin{array}{l}\text { Enter the total number of mechanical ventilators, NHSN Daily Report } \\ \text { including anesthesia machines and } \\ \text { portable/transport ventilators available in the } \\ \text { facility. Include BiPAP machines if the hospital uses } \\ \text { BiPAP to deliver positive pressure ventilation via } \\ \text { artificial airways. }\end{array}\end{array}$

Table 1 List of measures and agencies with mandated reporting in April 2020 for COVID-19 in Chicago 


\begin{tabular}{|c|c|c|c|c|}
\hline CDC PUI Form Field & In CCDA & In ELR & FHIR & $\begin{array}{c}\text { Other Data } \\
\text { Sources }\end{array}$ \\
\hline \multicolumn{5}{|c|}{$\begin{array}{l}\text { What is the current status of } \\
\text { this person? }\end{array}$} \\
\hline PUI- testing pending & $\begin{array}{c}\text { X (Lab test and } \\
\text { result } \\
\text { information) }\end{array}$ & & $X$ & \\
\hline PUI- tested negative & $\begin{array}{c}X \text { (Lab test and } \\
\text { result } \\
\text { information) }\end{array}$ & & $x$ & \\
\hline
\end{tabular}

Presumptive case (positive

local test)- confirmatory testing

pending

Presumptive case (positive

local test)- confirmatory tested

negative

Laboratory-confirmed case

X $\quad x \quad x$

Report date of PUI to CDC

Report date of case to CDC

\begin{tabular}{|c|c|c|c|c|}
\hline County of residence & $x$ & $x$ & $x$ & \\
\hline State of residence & $x$ & $x$ & $x$ & \\
\hline Ethnicity & $x$ & $x$ & $x$ & \\
\hline Race & $x$ & $X$ & $x$ & \\
\hline Sex & $x$ & $x$ & $x$ & \\
\hline DOB & $x$ & $x$ & $x$ & \\
\hline Age & $x$ & $x$ & $x$ & \\
\hline $\begin{array}{l}\text { Was the patient hospitalized? } \\
\text { And Date }\end{array}$ & $x$ & & $x$ & $\begin{array}{c}\text { ADT or } \\
\text { Census } \\
\text { Data }\end{array}$ \\
\hline $\begin{array}{l}\text { Was the patient admitted to an } \\
\text { intensive care unit (ICU) }\end{array}$ & & & $x$ & $\begin{array}{c}\text { ADT or } \\
\text { Census } \\
\text { Data }\end{array}$ \\
\hline
\end{tabular}

Did the patient receive

Custom 
mechanical ventilation (MV) or

Report intubation? (And Days of MV)

Did the patient receive ECMO?

Custom

Report

Did the patient die as a result

$$
x
$$

$X$

ADT of this illness? (And date)

Date of first positive specimen collection

Did the patient develop

$$
\text { X }
$$$$
x
$$

pneumonia?

Did the patient have acute $x$ respiratory distress syndrome?

Did the patient have another diagnosis/etiology for their illness?

Did the patient have an

abnormal chest $X$-ray?

Symptoms present during course of illness: (Symptomatic Asymptomatic Unknown )

Symptom onset date

Symptom resolution date

Is the patient a health care worker in the United States?

Does the patient have a history of being in a healthcare facility (as a patient worker or visitor) in China?

In the $\mathbf{1 4}$ days prior to illness onset- did the patient have any of the following exposures (check all that apply): 
Travel to Hubei

Travel to mainland China

Travel to other non-US country

Community contact with another lab-confirmed COVID-

19 case-patient

Any healthcare contact with another lab-confirmed COVID-

19 case-patient (Patient Visitor

HCW )

Exposure to a cluster of patients with severe acute lower respiratory distress of unknown etiology

Household contact with another lab- confirmed COVID-19 case -patient

Animal exposure

If the patient had contact with another COVID-19 case- was this person a U.S. case?

Under what process was the

PUI or case first identified?

(check all that apply):

Clinical evaluation leading to

PUI determination

Contact tracing of case patient

Routine surveillance

EpiX notification of travelers if

checked

Unknown

Other- specify

\section{Symptoms}

Fever $>100.4 \mathrm{~F}$ (38C) 


\begin{tabular}{|c|c|c|}
\hline Subjective fever (felt feverish) & & $X^{*}$ \\
\hline Chills & & $X^{*}$ \\
\hline Muscle aches (myalgia) & & $X^{*}$ \\
\hline Runny nose (rhinorrhea) & & $X^{*}$ \\
\hline Sore throat & & $X^{*}$ \\
\hline $\begin{array}{l}\text { Cough (new onset or } \\
\text { worsening of chronic cough) }\end{array}$ & & $X^{*}$ \\
\hline Shortness of breath (dyspnea) & & $X^{*}$ \\
\hline Nausea or vomiting & & $X^{*}$ \\
\hline Headache & & $X^{*}$ \\
\hline Abdominal pain & & $X^{*}$ \\
\hline $\begin{array}{l}\text { Diarrhea ( } \geq 3 \text { loose/looser than } \\
\text { normal stools/ } 24 \mathrm{hr} \text { period) }\end{array}$ & & $X^{*}$ \\
\hline Other & & \\
\hline Pre-existing medical conditions & & \\
\hline $\begin{array}{l}\text { Chronic Lung Disease (asthma } \\
\text { emphysema COPD) }\end{array}$ & $x$ & $x$ \\
\hline Diabetes Mellitus & $x$ & $x$ \\
\hline Cardiovascular disease & $x$ & $x$ \\
\hline Chronic Renal disease & $x$ & $x$ \\
\hline Chronic Liver disease & $x$ & $x$ \\
\hline $\begin{array}{l}\text { Immunocompromised } \\
\text { Condition }\end{array}$ & $x$ & $x$ \\
\hline $\begin{array}{l}\text { Neurologic } \\
\text { neurodevelopmental } \\
\text { intellectual disability }\end{array}$ & $x$ & $x$ \\
\hline Other chronic diseases & $x$ & $x$ \\
\hline If female- currently pregnant & & \\
\hline Current smoker & $x$ & $x$ \\
\hline Former smoker & $x$ & $x$ \\
\hline $\begin{array}{l}\text { Respiratory Diagnostic Testing } \\
\text { Test (Respiratory virus testing } \\
\text { panel information) }\end{array}$ & $x$ & $x$ \\
\hline
\end{tabular}


medRxiv preprint doi: https://doi.org/10.1101/2020.08.12.20173559; this version posted August 14, 2020. The copyright holder for this preprint (which was not certified by peer review) is the author/funder, who has granted medRxiv a license to display the preprint in perpetuity.

All rights reserved. No reuse allowed without permission.

\section{Testing}

NP Swab OP Swab Sputum

Other- Specify:

Table 2 Crosswalk table to compare coverage of PUI form fields and ELR, CCDA, and

\section{FHIR Resources}

*If Notes are shared through FHIR Resources 
medRxiv preprint doi: https://doi.org/10.1101/2020.08.12.20173559; this version posted August 14, 2020. The copyright holder for this preprint (which was not certified by peer review) is the author/funder, who has granted medRxiv a license to display the preprint in perpetuity.

\section{Data Field}

Total Records

Facilities

Lab-confirmed SARS-CoV-2

Facility Name / Reporting Lab

Patient First Name

Patient Last Name

Patient DOB

Patient Race

Patient Ethnicity

\begin{tabular}{|llll}
\hline Patient Address & Useful & $70,573(79.4 \%)$ & $165,715(49.7 \%)$ \\
\hline Patient City & Non-missing & $88,904(100.0 \%)$ & $385,073(94.2 \%)$ \\
\hline Useful & $88,254(99.3 \%)$ & $384,000(93.9 \%)$ \\
\hline Patient Zip & Non-missing & $88,902(100.0 \%)$ & $408,741(100.0 \%)$ \\
\hline \multirow{2}{*}{ Patient Home or Cell Phone* } & Useful & $88,902(100.0 \%)$ & $408,741(100.0 \%)$ \\
\hline & Non-missing & $88,780(99.9 \%)$ & $408,026(99.8 \%)$ \\
\hline Test name & Useful & $88,775(99.9 \%)$ & $407,918(99.8 \%)$ \\
\hline \multirow{2}{*}{ LOINC Code } & Useful & $21,451(24.1 \%)$ & $319,974(78.3 \%)$ \\
\hline \multirow{2}{*}{ Test results (raw feed) } & Non-missing & $88,906(100.0 \%)$ & $408,694(100.0 \%)$ \\
\hline & Useful & $88,906(100.0 \%)$ & $408,694(100.0 \%)$ \\
\hline & Non-missing & $0(\%)$ & $408,741(100.0 \%)$ \\
\hline & Useful & $0(\%)$ & $408,727(100.0 \%)$ \\
\hline
\end{tabular}


medRxiv preprint doi: https://doi.org/10.1101/2020.08.12.20173559; this version posted August 14, 2020. The copyright holder for this preprint (which was not certified by peer review) is the author/funder, who has granted medRxiv a license to display the preprint in perpetuity.

All rights reserved. No reuse allowed without permission.

\begin{tabular}{llll} 
Test results (imputed*) & Non-missing & $88,906(100.0 \%)$ & $408,741(100.0 \%)$ \\
\hline Test date & Useful & $88,906(100.0 \%)$ & $408,741(100.0 \%)$ \\
\hline Hospitalization $(\mathrm{y} / \mathrm{n})^{* *}$ & Non-missing & $86,159(96.9 \%)$ & $408,046(99.8 \%)$ \\
\hline Comorbidities & Useful & $86,139(96.9 \%)$ & $408,046(99.8 \%)$ \\
\hline & Useful & $88,906(100.0 \%)$ & $0(0.0 \%)$ \\
\hline & Non-missing & $88,906(100.0 \%)$ & $0(0.0 \%)$ \\
\hline
\end{tabular}

Table 3 Completeness of data submitted via CCDA and ELR

*Cell and Home phone not differentiated in ELR feed; Non-missing refers to populated data field; Useful refers to clean, complete information in data field; $<100 \%$ indicates "unknown" (race, ethnicity, address, etc); for address (PO Boxes, Unknown, Homeless, N/A); phone (no phone, bad number/not enough numbers); ZIP codes $<5$ digits or 99999 or 00000 or UUUUU etc. 
medRxiv preprint doi: https://doi.org/10.1101/2020.08.12.20173559; this version posted August 14, 2020. The copyright holder for this preprint (which was not certified by peer review) is the author/funder, who has granted medRxiv a license to display the preprint in perpetuity.

All rights reserved. No reuse allowed without permission.

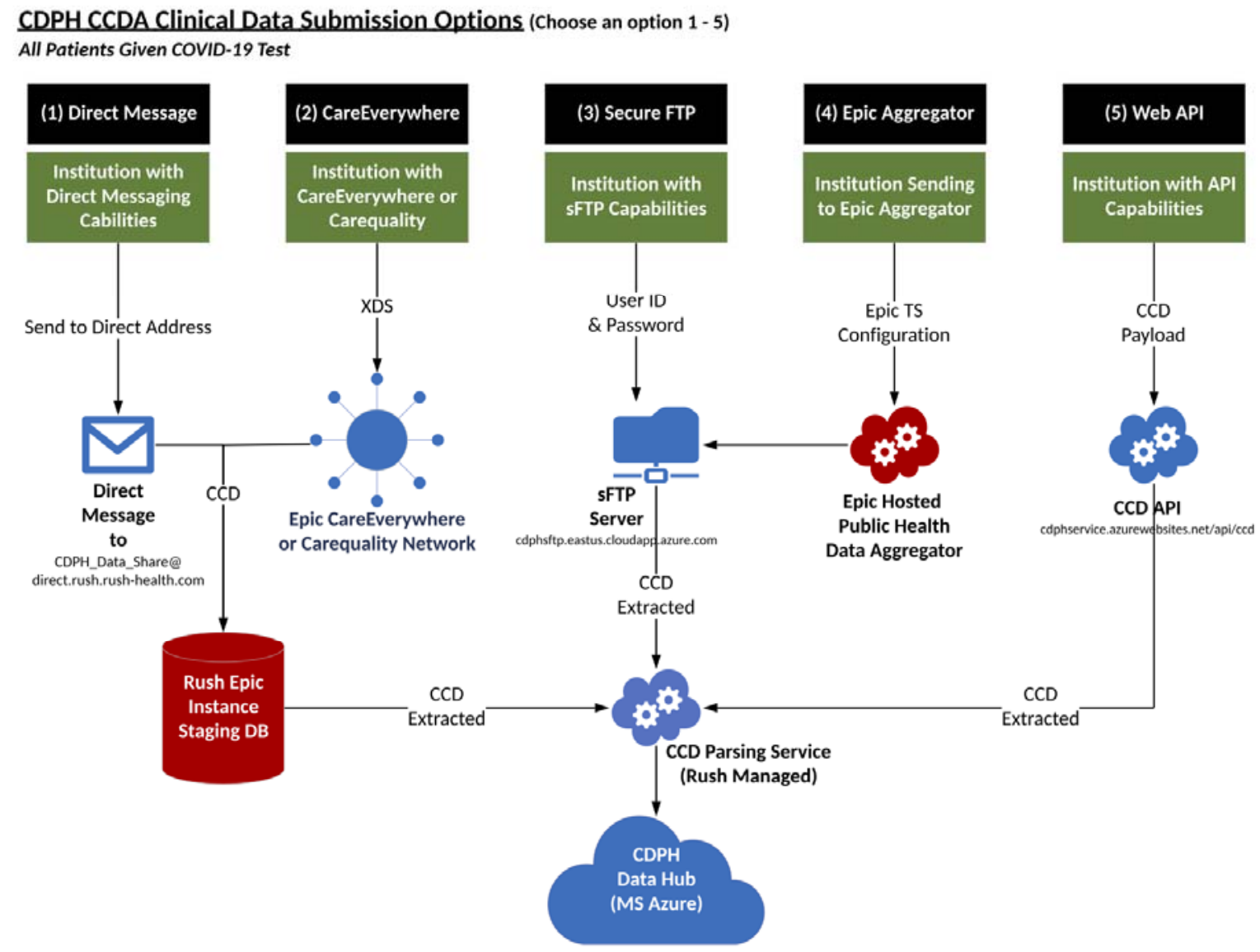

Figure 1 High level architecture of CDPH Data Hub 


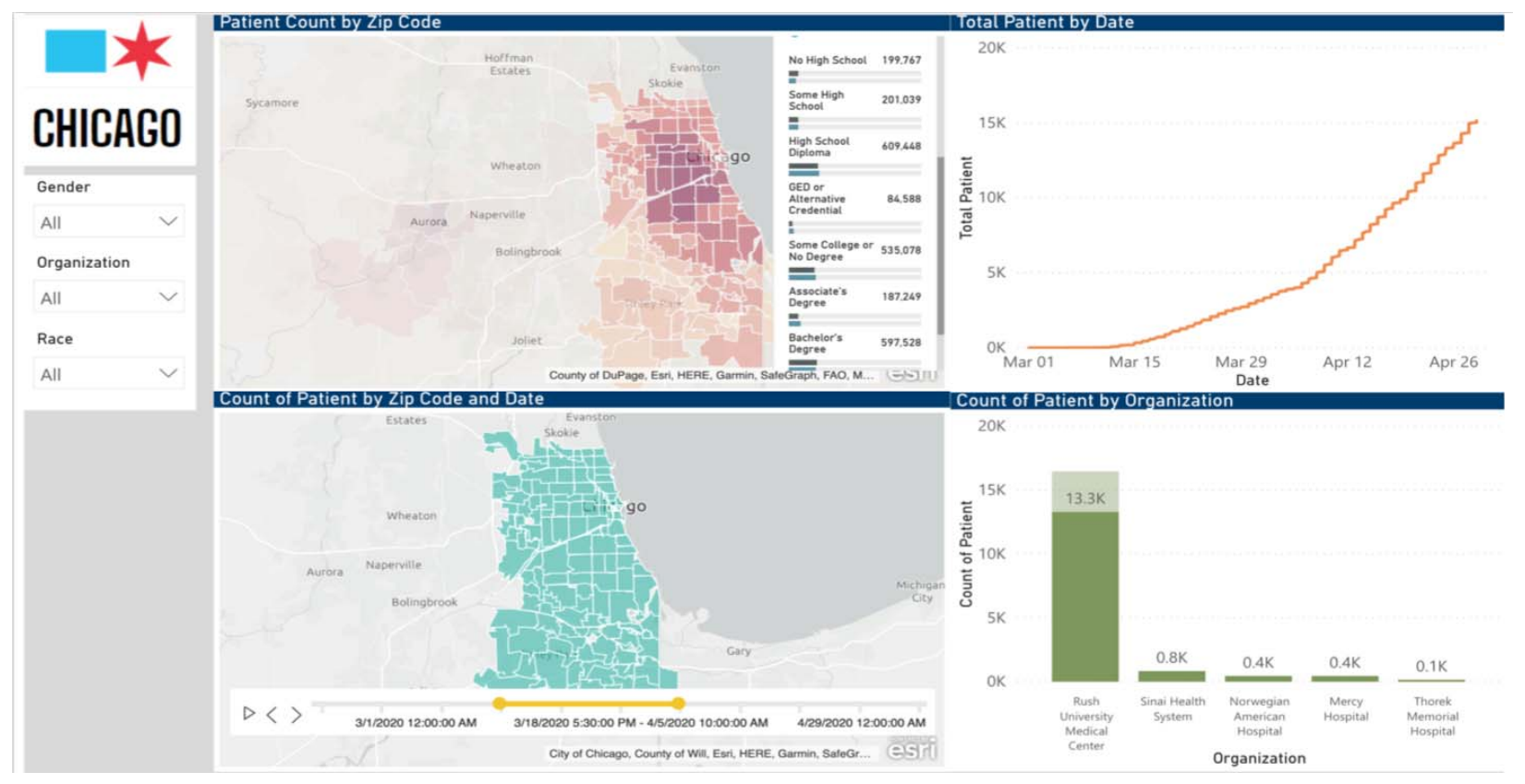

Figure 2 Epidemiologic dashboards for assessment of outbreak, CDPH data hub 
medRxiv preprint doi: https://doi.org/10.1101/2020.08.12.20173559; this version posted August 14, 2020. The copyright holder for this preprint (which was not certified by peer review) is the author/funder, who has granted medRxiv a license to display the preprint in perpetuity.

All rights reserved. No reuse allowed without permission. 